\title{
Hibrid képalkotás: klinikai evidenciák, lehetőségek
}

\author{
Trencsényi György dr. - Barna Sándor Kristóf dr. - Garai Ildikó dr. \\ ScanoMed Orvosi, Diagnosztikai, Kutató és Oktató Kft., Debrecen
}

\begin{abstract}
Napjainkban a radiológia és nukleáris medicina modern képalkotó berendezéseit ötvöző hibrid képalkotás fontos szerepet tölt be mind a transzlációs kutatási folyamatokban, mind pedig a klinikai diagnosztikában. A rutin képalkotó diagnosztikai eljárások közül a komputertomográffal vagy mágneses magrezonanciás képalkotással kombinált pozitronemissziós tomográfia, illetve egyfotonos emissziós komputertomográfiás vizsgálat jelenleg a legfejlettebb technikák közé tartozik, amelynek segítségével a funkcionális és a morfológiai képeket azonos pozícióban tudjuk egymásra vetíteni. A hibrid képalkotó berendezések a nagy érzékenységüknek, jó felbontásuknak köszönhetően hasznos információt nyújtanak a szervezetben zajló patológiás folyamatokról. Segítségükkel megismerhetők olyan biokémiai és patobiokémiai folyamatok, amelyek elengedhetetlenek a betegségek megértéséhez, kezeléséhez vagy egy új, gyógyszerjelölt molekula megismeréséhez. A klinikai és preklinikai in vivo nem invazív molekuláris képalkotó rendszerek segítségével a gyógyszerfejlesztés folyamata lerövidíthető, költségei csökkenthetók. Orv. Hetil., 2015, 156(52), 2110-2115.
\end{abstract}

Kulcsszavak: CT, hibrid képalkotás, MRI, PET, SPECT, transzlációs medicina

\section{Hybrid imaging: clinical evidence, opportunities}

Nowadays the hybrid imaging technologies which combine the modern equipments of radiology and nuclear medicine play an important role in both the translational research process and clinical diagnostics. Among the routine diagnostic imaging procedures positron emission tomography and single photon emission computed tomography combined with computed tomography or magnetic resonance imaging currently belong to the most advanced techniques allowing that functional and morphological images can be superimposed on each other in the same position. The hybrid imaging equipments provide useful information about the pathological processes in the body due to their high sensibility and resolution. Furthermore, with the help of these imaging modalities we can get acquainted with the biochemical and pathobiochemical processes that are essential for understanding and treating diseases, or getting acquainted with the behaviour of a new drug candidate. With the help of the clinical and preclinical non-invasive in vivo molecular imaging systems the drug developing process can be shortened and its costs can be reduced.

Keywords: CT, hybrid imaging, MRI, PET, SPECT, translational medicine

Trencsényi, Gy., Barna, S. K., Garai, I. [Hybrid imaging: clinical evidence, opportunities]. Orv. Hetil., 2015, 156(52), 2110-2115.

(Beérkezett: 2015. október 5.; elfogadva: 2015. október 29.)

\section{Rövidítések}

$\mathrm{CT}$ = komputertomográfia; $\mathrm{MRI}=$ mágneses magrezonanciás képalkotás; PET = pozitronemissziós tomográfia; SPECT = single photon (egyfotonos) emissziós komputertomográfia

\section{Hibrid képalkotás a klinikumban}

A hibrid technológiák előnye, hogy az egymás utáni pozitronemissziós tomográfia (PET), single photon (egyfotonos) emissziós komputertomográfia (SPECT), kom- putertomográfia (CT), mágneses magrezonanciás (MR) leképezések pontos regisztrációja történik. Így a különböző információtartalommal rendelkező képek egymás utáni értékelése és együttes értelmezése nemcsak megkönnyíti a leletezés folyamatát, hanem nagymértékben fokozza a diagnosztikai megbízhatóságot is.

Hibrid technológiákat 15 éve alkalmaznak a klinikai gyakorlatban. Elsődlegesen a CT kombinációja PET- és SPECT-modalitással azt a célt szolgálta, hogy egy pontos, röntgensugár-alapú elnyelési térkép készüljön a szö- 


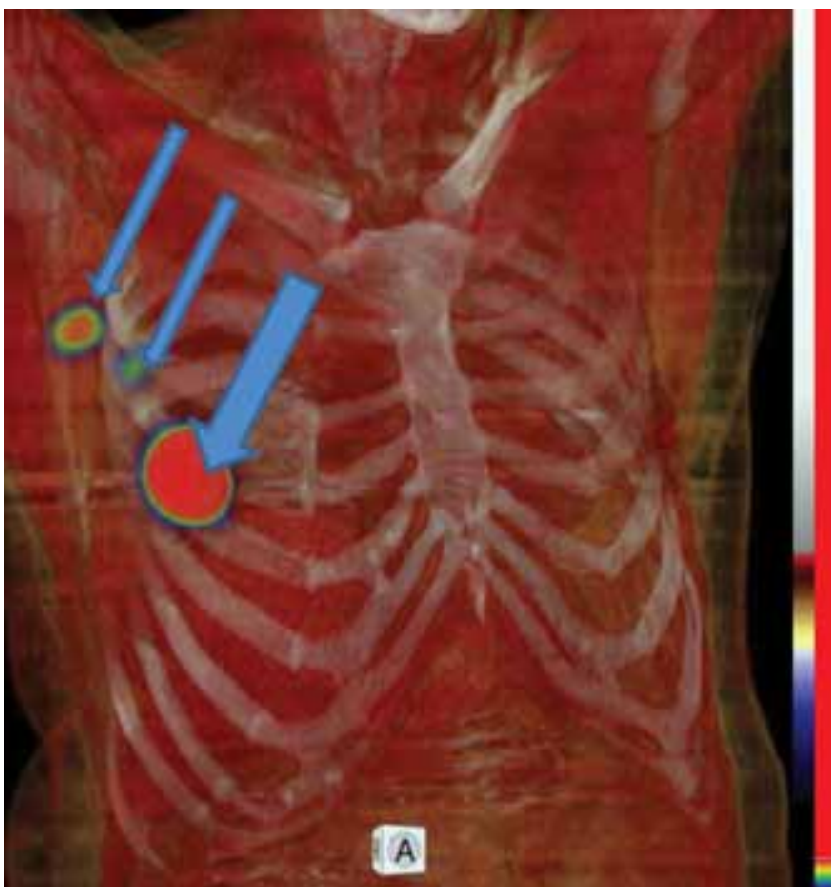

1. ábra

Emlőtumoros beteg sentinelnyirokcsomó-vizsgálata Tc99 Senti-Scint-tel (Medi-Radiopharma) végzett SPECT/CT-vel (AnyScan SC, Mediso). Vastag nyíl: a beadás helye, vékony nyíl: a két jelölt axillaris nyirokcsomó (volume rendering image)

vetekról a képminőség javítására. Mióta diagnosztikus CT-vel kombinált készülékeket hoztak forgalomba, azok klinikai haszna túlmutat a képminőség javításán. Az elnyelés által korrigált képek ${ }^{99 \mathrm{~m} T c-M I B I-v e l ~ v e ́ g z e t t ~ s z i ́ v-~}$ izom-perfúziós felvételeken javítják a diagnosztikai pontosságot, azáltal, hogy a rekesz vagy emlő okozta elnyelési müterméket eliminálja, ezzel az álpozitív esetek számát jelentősen csökkenti [1]. A pozitronsugárzókkal végzett vizsgálatok esetén az elnyeléskorrekció egyszerú

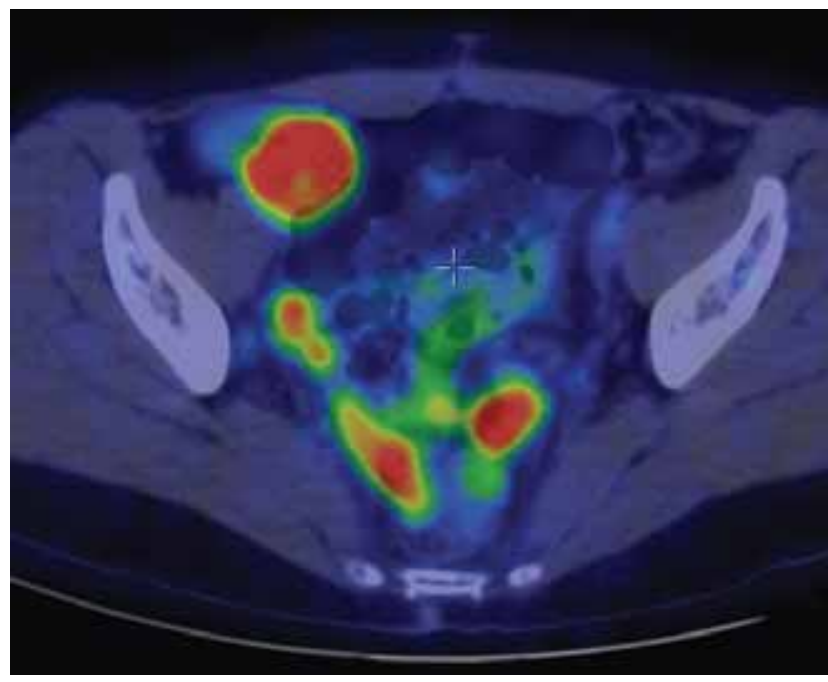

2. ábra

Ovariumcarcinoma peritonealis metasztázisai intenzíven halmozzák a F18 FDG-t PET/CT (Gemini TF, Philips) vizsgálaton (axiális sík)

mérési lehetőséget ad arra, hogy a metabolikus aktivitást jelző radioaktivitást egy laesión belül számszerúen jellemezzük, s ez összevethető legyen más vagy későbbi időpontban végzett vizsgálatokkal. A hibrid technológia másik nagy előnye a klinikai alkalmazásban, hogy pontosan lokalizálhatók a patológiás dúsulások és nagy biztonsággal elkülöníthetők a fiziológiás halmozásoktól. Egy közelmúltban megjelent multicentrikus tanulmányban Jimenez-Heffernan és mtsai [2] igazolták, hogy a SPECT/CT vizsgálat több nyirokcsomót mutat ki és biztosabban ítéli meg a nyirokdrenázs útját, mint a konvencionális planáris vizsgálat (1. ábra). Wong és mtsai [3] metaanalízis-vizsgálatukban beszámoltak arról, hogy a 99mTc-MIBI fúziós SPECT/CT képalkotással pontosabban detektálhatók a hiperfunkcionáló parathyreoidea-
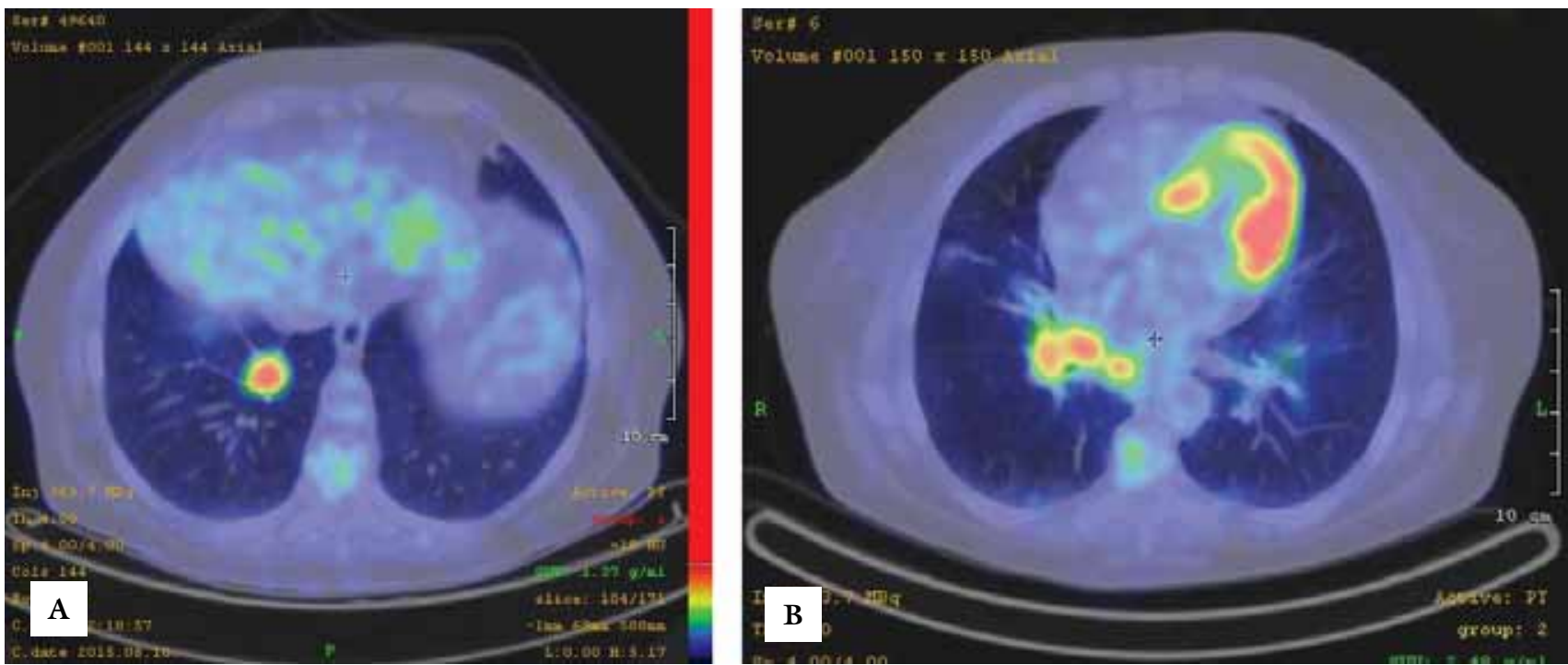

3. ábra

Tüdőadenocarcinoma stagingvizsgálata. A primer folyamat mellett (A) azonos oldali hilaris metabolikusan aktív patológiás nyirokcsomók (B) ábrá zolódtak F18 FDG PET/CT (AnyScan PC, Mediso) vizsgálaton (axiális sík) 


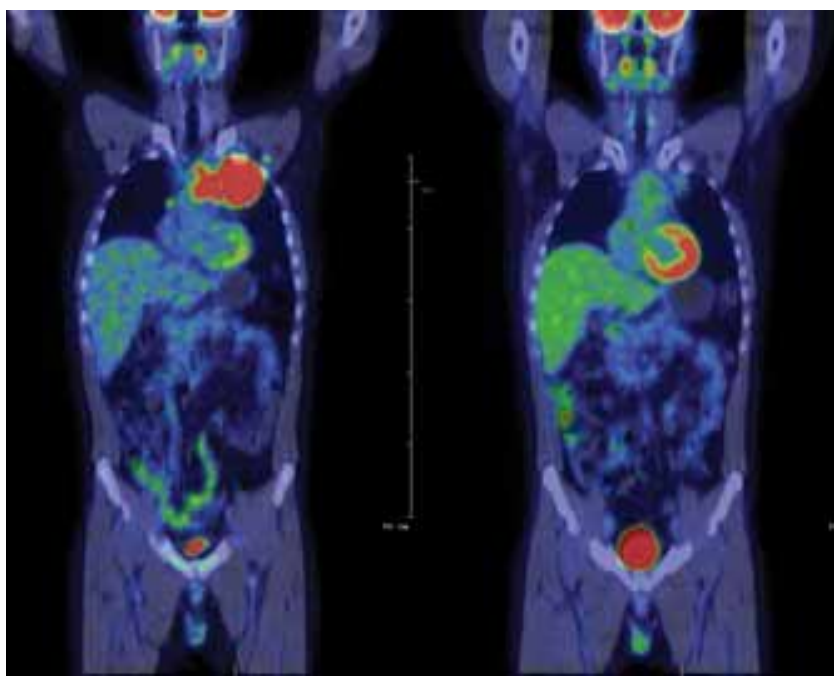

4. ábra

Lymphomakövetés. Klasszikus Hodgkin-lymphomás beteg primer staging és két ciklus kemoterápiát követő úgynevezett inte rim F18 FDG PET/CT (Gemini TF, Philips) vizsgálata. A kemoszenzitivitást jól jelzi a tumortömeg jelentősen csökkenó metabolikus aktivitása (coronalis sík)

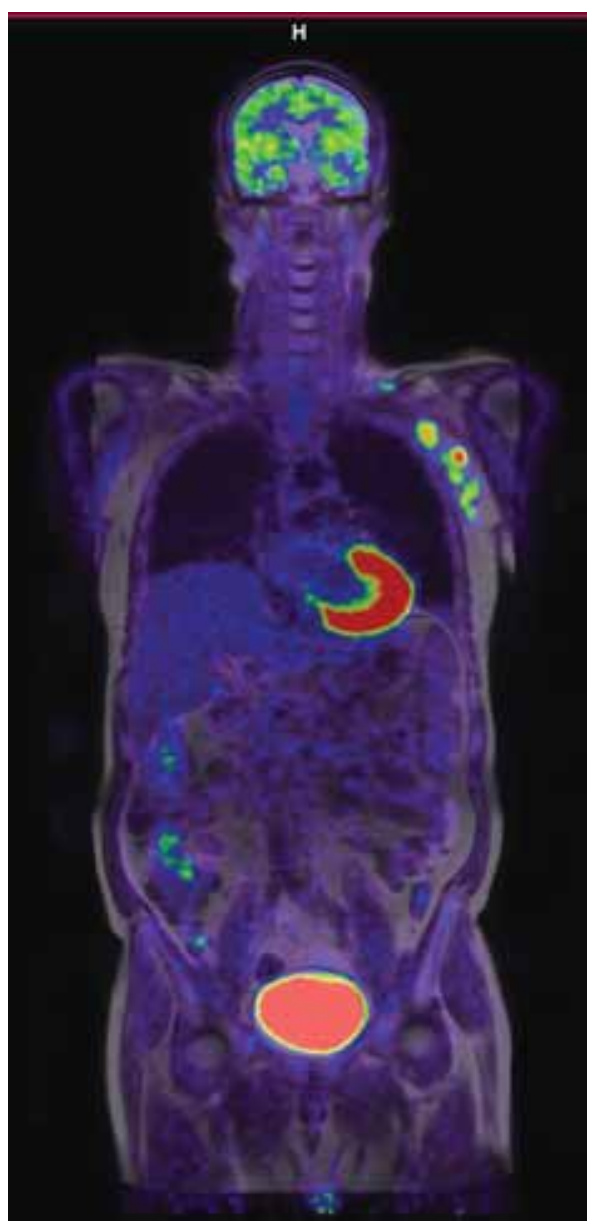

5. ábra

PET/MRI: DLBCL primer staging F18 FDG PET/MRI (Biograph $\mathrm{mMR}$ PET/MR) vizsgálat. Bal axillaris patológiás nyirokcsomók ábrázolódtak a kiváló lágyszöveti felbontást adó PET/MR felvételen (coronalis sík). A felvételek a Kaposvári Egyetem PET Medicopus Kft. PET-központjában üzemeló PET/MR (Biograph mMR, Siemens) berendezéssel készültek. Dr. Tóth Zoltán fóorvos úr szívességéből adenomák, amely a mútéti tervezéshez fontos kiegészítő információt ad. A latens gyulladásos folyamatok, a vérzés helyének kimutatása, a máj fokális laesióinak differenciáldiagnosztikája mindig kihívást jelent a klinikus számára. A morfológiai/anatómiai képalkotás funkcionális folyamatokkal való összevetése számos esetben egyértelmú végleges diagnózist biztosít. A ${ }^{18} \mathrm{~F}-\mathrm{FDG}\left(2-\left[{ }^{18} \mathrm{~F}\right]\right.$-fluoro2-deoxi-d-glükóz - FDG) a legáltalánosabban használt, elsősorban onkológiai indikációjú PET-farmakon. Sok esetben úgy gondoljuk, hogy a malignus tumorok kimutatása ezzel a radiofarmakonnal egyszerü, hiszen a daganat magas metabolikus aktivitása, magas FDG-felvétele ezt érzékenyen jelzi. Ugyanakkor fiziológiásan magas aktivitású területek elfedhetnek malignitást, s alacsony metabolikus aktivitású daganatok sem halmozzák kórjelzően az FDG-t. Branstetter és mtsai [4] megfigyelése szerint például fej-nyak tumoros betegeknél a fiziológiás dúsulások miatt több esetben elvétették volna a diagnózist, ha CT-felvétel nem készült volna. Ugyanakkor az abdominalis, kismedencei anatómia nagyon egyedi lehet a szervek eltérő nagysága, a belek változó lokalizációja, a vesék alaki deformitásai, az ureterek lefutása, tágassága stb. miatt. Így a pontos lokalizáció egy fokális dúsulás esetében anatómiai háttér nélkül bizonytalan lenne. Peritonealis carcinomatosis igen érzékenyen kimutatható FDG PET/CT vizsgálattal a metasztatikus gócok intenzív farmakonhalmozása és a lokalizáció által (2. ábra). Az FDG PET/CT vizsgálat szerepe, előnye más képalkotókkal szemben számos daganat, mint lymphomák, tüdőrák, colorectalis daganatok, fej-nyaki és nyelőcsődaganatok onkológiai stagingjében, restagingjében mára bizonyítottan igazolt [5] (3. ábra). Nagy lépést jelentett az onkológiában annak felismerése, hogy az FDG PET/ CT alkalmas terápiahatékonyság megítélésére, lemérhető vele az alkalmazott onkológiai terápia sikeressége vagy hatástalansága. Újraértékelték a követéses vizsgálatok morfológiai kritériumrendszerét szolid tumorokban és lymphomákban, beleépítve a metabolikus képalkotás adta lehetőségeket is [6]. Földrészeken átívelő, éveken

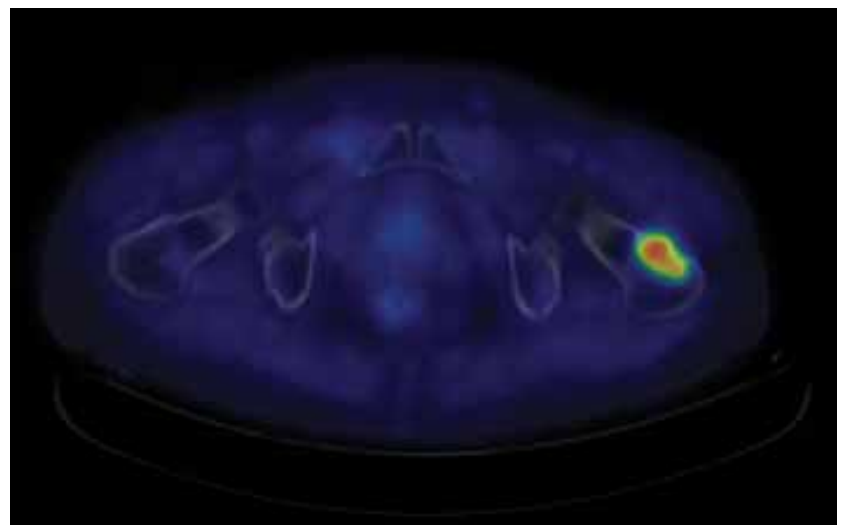

6. ábra Prostataadenocarcinomás beteg restaging C11 kolin PET/CT (Gemini TF, Philips) vizsgálata. A bal humerusfejben levő scleroticus laesio intenzív kolinmetabolizmusa megerősítette a metasztatikus folyamat diagnózisát (axiális sík) 


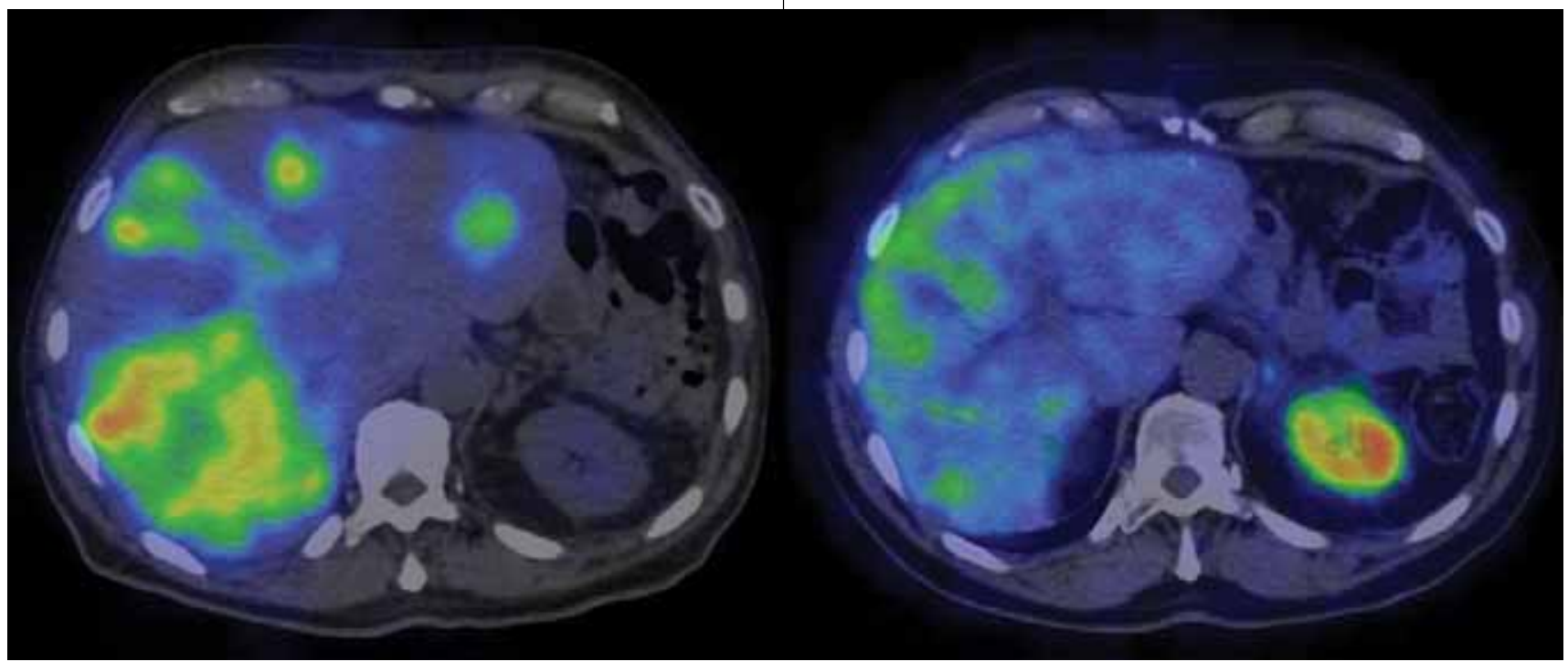

7. ábra

Differenciált neuroendokrin tumor szomatosztatinreceptor SPECT/CT (AnyScan SC, Mediso) vizsgálata Tc99m Tektrotyd (Polatom) radiofarmakonnal Y90 DOTATOC-kezelés előtt és után (axiális sík). Kezelés előtt szomatosztatinreceptorban gazdag daganat intenzív halmozást mutat, kezelés után nem látható kórjelző halmozás ugyanott. A nagy fajlagosságú radiofarmakonnal lemérhető a specifikus radioizotópos terápia hatékonysága

keresztül végzett multicentrikus tanulmány eredménye a lymphomák FDG PET/CT alapú kritériumrendszerének újragondolása is. Az FDG $\mathrm{PET} / \mathrm{CT}$ vizsgálatot nemcsak a terápiarezisztencia megítélésére tartják indokoltnak, hanem a korai - akár 1-2 ciklus - kemoterápia utáni metabolikus válasz, az úgynevezett kemoszenzitivitás lemérésére is. Így optimalizálható, személyre szabható lesz a kezelés [7] (4. ábra).

Mi sem bizonyítja jobban a hibrid technológia létjogosultságát a gyakorlatban, mint az a tény, hogy 2001 és 2005 között a legtöbb PET-szkennert lecserélték PET/ CT-re, s az új installálások során már kizárólag hibrid kamera kerül üzembe helyezésre.

A PET/CT vizsgálat során készült CT bizonyos lokalizációkban, például kismedencei szervek, agy, máj stb., nem olyan megfelelő szöveti felbontást biztosít, ami segítené a pontosabb diagnózis felállítását. Agydaganatokban MR-vizsgálat esszenciális a terápia pontos terve-

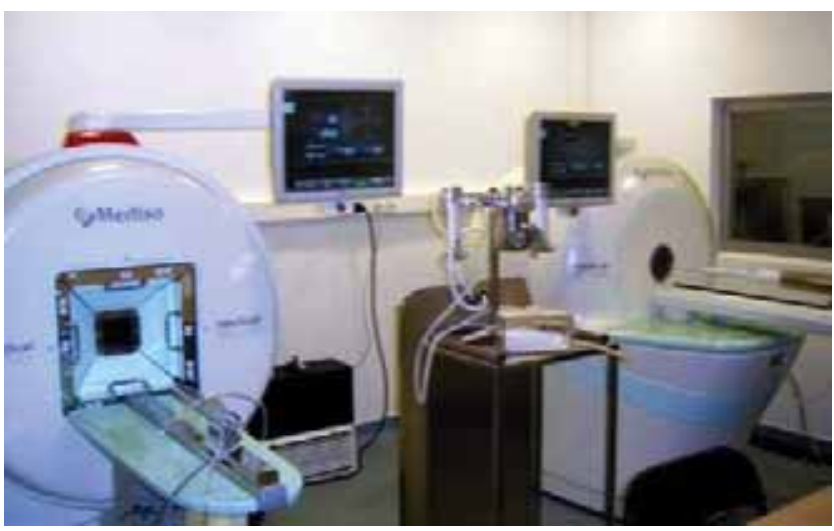

8. ábra

Modern preklinikai képalkotó laboratórium kis laboratórium állatok vizsgálatára alkalmas PET/MRI, valamint SPECT/CT kamerákkal zéséhez, a daganat kiterjedésének, környezethez való viszonyának megítéléséhez, ugyanakkor lényeges ismerni a metabolikus aktivitását is, amelynek prognosztikai jelentősége van. Ezért nem volt meglepő lépés, hogy a nagy kameragyártók néhány évvel a PET/CT piacra kerülése után egymással versengve mutatták be az új hibrid technológiájukat, a PET/MR-t. Akkor még kérdéses volt a helye a diagnosztikai algoritmusban, de a gyakorlatban

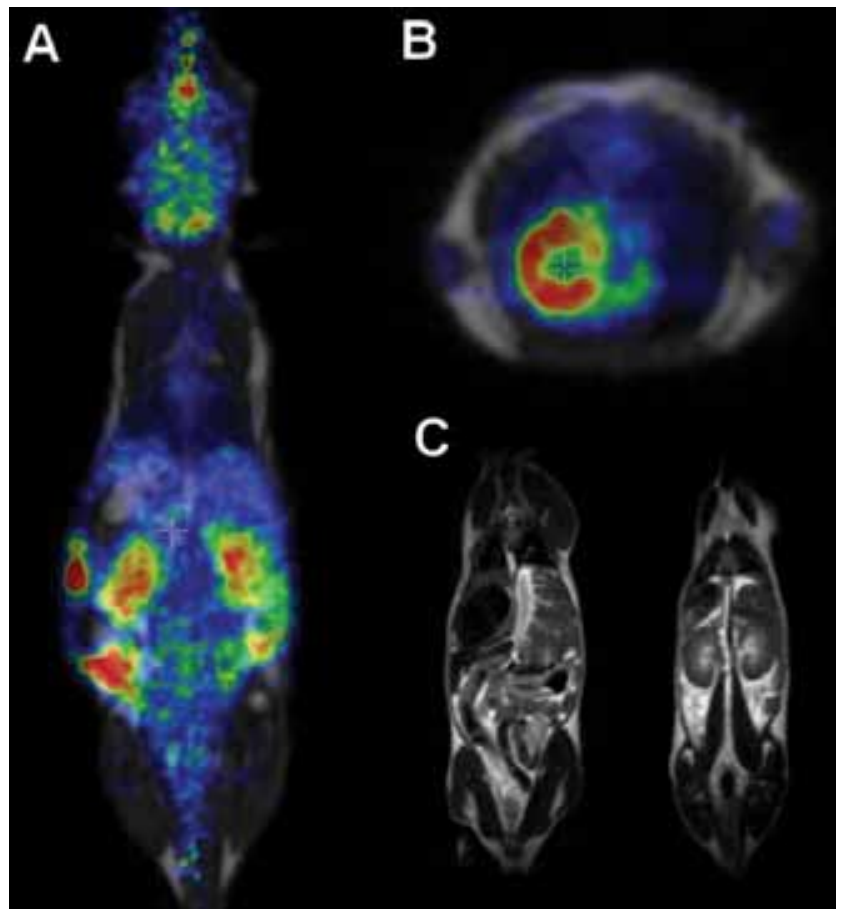

9. ábra

BALB/c egér PET/MRI felvétele 50 perccel ${ }^{18}$ FDG intraperitonealis adása után. 10 perces statikus felvételek. A: Coronalis sík. B: Axiális sík. C: BALB/c egér MR-felvételei. Coronalis sík. A felvételek Mediso nanoScan PET/MRI preklinikai képalkotó berendezéssel készültek 
való alkalmazás újabb és újabb klinikai relevanciát teremtett [8]. Egy újonnan megjelent közleményben Beiderwellen és mtsai FDG PET/MR vizsgálattal pontosabban mutatták ki a májmetasztázist, mint a PET/CT (PET/ CT: 82,4\%; PET/MRI: 96,1\%) [9]. Grueneisen és mtsai tanulmányukban úgy találták, hogy a nőgyógyászati daganatok restagingjében a PET/MR a PET/CT-hez képest magasabb diagnosztikai értékkel bír [10]. A PET/ MRI alkalmazása azonban kiemelkedő a neurológiai képalkotásban - nemcsak az agydaganatok kivizsgálásában, hanem a neurodegeneratív kórképek, epilepszia diagnosztikájában is - a finom szöveti felbontása miatt, valamint a gyermekgyógyászatban az alacsonyabb sugárterhelés miatt [11] (5. ábra).

A hibrid technika alkalmazásának szélesebb klinikai alkalmazási lehetőségeit az újabb és egyre fajlagosabb gamma- és pozitronsugárzó izotóppal jelölt radiofarmakonok jelentik, amelyek érzékenyebben jellemzik a daganat biológiai viselkedését, pontosabb diagnózist adnak (6. ábra), alkalmasak terápiahatékonyságot megítélő követő biomarkerként viselkedni (7. ábra). Ugyancsak izgalmas terület a daganat szöveti metabolizmus heterogenitásvizsgálata, amelyre az egyre érzékenyebb, nagyobb felbontású kamerák, továbbá a pontosabb és bonyolultabb matematikai algoritmusokat alkalmazó értékelőszoftverek adnak lehetőséget. Ezt ma már mérni tudjuk, de a klinikai relevanciája, értéke még vitatott.

\section{A hibrid képalkotás szerepe a transzlációs kutatásokban}

A transzlációs medicina vagy más néven transzlációs kutatás képezi a hidat az alapkutatások és a klinikai alkalmazások között. Magában foglalja az alapkutatások humán terápiákban alkalmazható hatásvizsgálatát, a betegségek biológiai vizsgálatát, a humán betegségek kezelésének új fejlesztéseit, olyan nem humán és nem klinikai vizsgálatokat, amelyek az alapját képezhetik új klinikai alkalmazásoknak, valamint idetartoznak a gyógyszerfejlesztés klinikai 1-3 fázisának vizsgálatai. Ha a preklinikai vizsgálatok során az emberben előforduló betegségek megfeleló állatmodelles változatainak vizsgálatakor a kutatók azonos módszereket alkalmaznak, mint az ezeket követő humán klinikai kísérleti fázisban, akkor a preklinikai tesztelés eredményei pontosabban tükrözik a humán vizsgálatok eredményeit. Ebben a folyamatban van helye és kiemelkedő jelentősége az úgynevezett transzlációs képalkotásnak, amelynek köszönhetően kifejlesztett képalkotó technikák, jelölőanyagok, kiértékelőmódszerek könnyebben és hamarabb átültethetők a klinikai gyakorlatba.

Egy új - akár radioaktívan jelölt - molekula humán szervezetben történő vizsgálatát preklinikai kutatásoknak, vizsgálatoknak kell megelőznie, amely alapján eldönthető, hogy az adott jelölt molekula alkalmas-e a további - humán - vizsgálatokra adott formájában. A preklinikai vizsgálatok többek között magukban fog- lalják a jelzett molekula in vitro sejtes rendszereken, illetve az in vivo állatmodelleken történő vizsgálatát [12, 13]. Sajnos, még ma sem rendelkezünk olyan in vitro molekuláris biológiai módszerekkel, amelyek segítségével a különböző (például daganatos) megbetegedések lefolyásának minden aspektusát vizsgálni tudjuk (elsősorban igaz ez például a tumorok metasztatizáló képességére), illetve az in vitro vizsgálatok a radioaktívan jelzett molekulák, gyógyszermolekulák élő szervezetre gyakorolt hatását, szervezeten belüli megoszlását, anyagcserefolyamatokba történő kapcsolódását nem tudják tökéletesen modellezni. Ezekhez a vizsgálatokhoz in vivo kísérletekre, állatmodellekre, állatkísérletekre van szükség $[14,15]$.

A preklinikai vizsgálatok során egy radionukliddal jelölt molekula szervezeten belüli időbeni eloszlását modern, nem invazív képalkotó berendezésekkel vizsgálhatjuk kvantitatív módon. Az idetartozó képalkotó eszközök, mint a PET, valamint a SPECT a humán klinikai gyakorlatban igen gyakran alkalmazott diagnosztikai eszközzé váltak az elmúlt majd' három évtized során. Ezt azzal magyarázhatjuk, hogy a módszer igen nagy érzékenységü, és segítségével noninvazív módon kaphatunk kvantitatív képet a szervezet belső állapotáról.

A módszer kísérleti alkalmazása in vivo preklinikai vizsgálatokhoz már a kezdetektől is ígéretesnek tünt, így igen nagy ütemben indultak fejlődésnek a kisállat-PETés -SPECT-kamerák, amelyek már a kis laboratóriumi állatok (egér, patkány) vizsgálatához szükséges milliméteres, illetve az alatti felbontóképességgel rendelkeztek. A radiológiai képalkotó diagnosztikai eljárások közül a CT-vel vagy MR-vel kombinált PET-, illetve SPECTvizsgálat jelenleg a legfejlettebb technikák közé tartozik, amelynek segítségével funkcionális és morfológiai képeket azonos pozícióban tudunk egymásra vetíteni. A kisállat PET/CT hibrid képalkotó technológia forradalmi változásokat hozott az onkológiai, kardiológiai és neurológiai kutatásokban. E fejlődésnek adtak újabb lendületet és jövőbeni iránymutatást a preklinikai PET/MRI berendezések (8. ábra), illetve a legújabb fejlesztésű SPECT/MRI készülékek. A preklinikai multimodális berendezéseknek köszönhetően CT-vel, valamint MRIvel kiegészítve pontosan meghatározhatjuk a PET, illetve SPECT nyújtotta funkcionális információ anatómiai lokalizációját [16, 17] (9. ábra).

E hibrid képalkotó berendezések egyik nagy előnye, hogy ugyanazon kísérleti állat többször vizsgálható, hiszen nincs szükség az állat terminálására ahhoz, hogy kvantitálható információhoz jussunk a jelzett molekula adott idő alatt történő szervezeten belüli eloszlásáról, lehetővé válik az élettani, kórélettani folyamatok hosszú távú nyomon követése, a kezelések hatékonyságának kimutatása stb. [18]. A preklinikai képalkotó berendezések alkalmazásával csökkenthető a kísérleti állatok száma, továbbá noninvazív tulajdonságukból adódóan eleget tesznek az állatkísérletekkel szemben elvárt „3R” stratégiának (replacement, reduction and refinement), amely 
megköveteli a kísérleti állatok számának redukálását, valamint a kezelésük technikáinak finomítását.

E modern hibrid készülékek, valamint a mögöttük álló úgynevezett gyưjtő és képrekonstrukciós szoftverek fejlődésével egyre pontosabb, értékelhetőbb (például mozgási mütermék kiküszöbölése, résztérfogathatás-korrekció) kvantitatív felvételeket kapunk a kisállatokban zajló fiziológiás és patológiás folyamatokról. A módszer érzékenységének, felbontásának növelésével egyre alacsonyabb injektálandó dózisokra van szükség, valamint rövidül a gyüjtési, vizsgálati idő, amelyek szintén olyan tulajdonságai e modern képalkotó eszközöknek, amelylyel csökkenthető a kísérleti állatot érő stressz.

A molekuláris biológia fejlődésével újabb és újabb molekuláris célpontok, targetek jelennek meg, aminek köszönhetően az eddig gyakran használt és többnyire nem specifikus (például: ${ }^{18} \mathrm{FDG}$ ) radiofarmakonok mellett felmerült az igény új, specifikus molekulák iránt. A PET, illetve SPECT leképezésre alkalmas radionuklidokkal jelzett új targetspecifikus molekulákkal jól monitorozhatók a receptortargetált terápiák, génterápiák és megteremtik az alapjait az úgynevezett „theranostics” alkalmazásoknak, új utakat nyitva a preklinikai képalkotásban [17]. Az idetartozó radionukliddal jelzett molekulák leggyakrabban antitestek (például: ${ }^{89} \mathrm{Zr}-\alpha \mathrm{HER} 2-\mathrm{Fab}$ [19]), receptorhoz kötődő peptidek (például: ${ }^{68} \mathrm{Ga}-\mathrm{NOTA}-\mathrm{NGR}$ [20]), targetált nanorészecskék (például: ${ }^{89} \mathrm{Zr}$-rHDL [21]), amelyek jelentős részének terápiás vonatkozása is van, hiszen alkalmasak mind terápiás izotópok, mind pedig gyógyszermolekulák specifikus célba juttatására. Mindezeknek köszönhetően a preklinikai képalkotó berendezések alkalmazásával a sokszor igen hosszú és költséges gyógyszerkutatás, gyógyszerfejlesztés folyamata lerövidíthető, költségei csökkenthetők.

Anyagi támogatás: A közlemény megírása anyagi támogatásban nem részesült.

Szerzői munkamegosztás: T. Gy., B. S. K., G. I.: Kézirat megszövegezése, irodalomkutatás.

A cikk végleges változatát mindhárom szerző elolvasta és jóváhagyta.

Érdekeltségek: A szerzőknek nincsenek érdekeltségeik.

\section{Irodalom}

[1] Mathur, S., Heller, G. V., Bateman, T. M., et al.: Clinical value of stress-only Tc-99m SPECT imaging: importance of attenuation correction. J. Nucl. Cardiol., 2013, 20(1), 27-37.

[2] Jimenez-Heffernan, A., Ellmann, A., Sado, H., et al.: Results of a prospective multicenter international atomic energy agency sentinel node trial on the value of SPECT/CT over planar imaging in various malignancies. J. Nucl. Med., 2015, 56(9), 1338-1344.
[3] Wong, K. K., Fig, L. M., Gross, M. D., et al.: Parathyroid adenoma localization with $99 \mathrm{mTc}$-sestamibi SPECT/CT: a meta-analysis. Nucl. Med. Commun., 2015, 36(4), 363-375.

[4] Branstetter, B. F. 4th, Blodgett, T. M., Zimmer, L. A., et al.: Head and neck malignancy: is PET/CT more accurate than PET or CT alone? Radiology, 2005, 235(2), 580-586.

[5] Bockisch, A., Freudenberg, L. S., Schmidt, D., et al.: Hybrid imaging by SPECT/CT and PET/CT: proven outcomes in cancer imaging. Semin. Nucl. Med., 2009, 39(4), 276-289.

[6] Wabl, R. L., Jacene, H., Kasamon, Y., et al.: From RECIST to PERCIST: evolving considerations for PET response criteria in solid tumors. J. Nucl. Med., 2009, 50(Suppl. 1), 122S-150S.

[7] Cheson, B. D., Fisher, R. I., Barrington, S. F., et al.: Recommendations for initial evaluation, staging, and response assessment of Hodgkin and non-Hodgkin lymphoma: the Lugano classification. J. Clin. Oncol., 2014, 32(27), 3059-3068.

[8] Borbély, K.: New challenges and new potentials in the management of patients in oncology: PET/MRI clinical applications. [Újdonságok és új lehetőségek az onkológiai betegek terápiás vezetésében: PET/MR klinikai alkalmazások.] Magy. Onkol., 2015, 59(1), 10-16. [Hungarian]

[9] Beiderwellen, K., Geraldo, L., Rublmann, V., et al.: Accuracy of [18F]FDG PET/MRI for the detection of liver metastases. PLoS ONE, 2015, 10(9), e0137285.

[10] Grueneisen, J., Schaarschmidt, B. M., Heubner, M., et al.: Implementation of FAST-PET/MRI for whole-body staging of female patients with recurrent pelvic malignancies: A comparison to PET/CT. Eur. J. Radiol., 2015, 84(11), 2097-2102.

[11] Garibotto, V., Heinzer, S., Vulliemoz, S., et al.: Clinical applications of hybrid PET/MRI in neuroimaging. Clin. Nucl. Med., 2013, 38(1), el3-e18.

[12] Jang, B. S.: MicroSPECT and MicroPET imaging of small animals for drug development. Toxicol. Res., 2013, 29(1), 1-6.

[13] Mahajan, A., Goh, V., Basu, S., et al.: Bench to bedside molecular functional imaging in translational cancer medicine: to image or to imagine? Clin. Radiol., 2015, 70(10), 1060-1082.

[14] Koba, W., Jelicks, L. A., Fine, E. J.: MicroPET/SPECT/CT imaging of small animal models of disease. Am. J. Pathol., 2013, $182(2), 319-324$.

[15] Pomper, M. G., Lee, J. S.: Small animal imaging in drug development. Curr. Pharm. Des., 2005, 11(25), 3247-3272.

[16] Franc, B. L., Acton, P. D., Mari, C., et al.: Small-animal SPECT and SPECT/CT: important tools for preclinical investigation. J. Nucl. Med., 2008, 49(10), 1651-1663.

[17] McDermott, S., Kilcoyne, A.: Molecular imaging-its current role in cancer. QJM, 2015 Aug 7. pii: hcvl41. [Epub ahead of print]

[18] Koo, V., Hamilton, P. W., Williamson, K.: Non-invasive in vivo imaging in small animal research. Cell. Oncol., 2006, 28(4), 127-139.

[19] Mendler, C. T., Gehring, T., Wester, H. J., et al.: ${ }^{89} \mathrm{Zr}$-labeled versus ${ }^{124}$ I-labeled $\alpha$ HER2 Fab with optimized plasma half-life for high-contrast tumor imaging in vivo. J. Nucl. Med., 2015, 56(7), 1112-1118.

[20] Shao, Y., Liang, W., Kang, F., et al.: ${ }^{68}$ Ga-labeled cyclic NGR peptide for microPET imaging of $\mathrm{CD} 13$ receptor expression. Molecules, 2014, 19(8), 11600-11612.

[21] Pérez-Medina, C., Tang, J., Abdel-Atti, D., et al.: PET imaging of tumor-associated macrophages with ${ }^{89} \mathrm{Zr}$-labeled high-density lipoprotein nanoparticles. J. Nucl. Med., 2015, 56(8), 12721277.

(Trencsényi György dr., Debrecen, Nagyerdei krt. 98., 4032 e-mail: trencsenyi.gyorgy@scanomed.hu) 